\title{
A Note on Intertemporal Fiscal Competition and Redistribution
}

\author{
KERSTEN KELLERMANN \\ kerstenkellermann@bluewin.ch \\ Center of Public Finance, University of Fribourg, Beauregard 13, CH-1700 Fribourg, Switzerland
}

\begin{abstract}
This paper studies fiscal competition among jurisdictions in a dynamic framework, where the degree of mobility of private capital across jurisdictions boundaries is perfect. The optimal tax on mobile capital is a source tax that taxes away factor rents. Further we show that taxation of mobile capital can redistribute income in favor of the immobile factor labor. This is because the factor rents generated by public inputs and appropriated by mobile capital exceed the efficient level of public expenditure for investments.
\end{abstract}

Keywords: fiscal competition, tax competition, public inputs, source tax, capital taxation, capital mobility

JEL Code: H21, H23, H42, H71

\section{Introduction}

A common paradigm in the field of tax competition is that taxes on mobile capital are not effective instruments to finance social programs or transfers to private households and thus redistribution of income (Oates, 1999). The standard analysis of the incidence of a source tax on capital revenue levied by a small open jurisdiction puts forth that the tax is borne by the immobile factor labor or local consumers. The struggle between capital and labor over the distribution of the national income thus cannot be influenced by the government in favor of immobile workers. The economic intuition behind this view is that under the source principle of taxation there is a tendency to equate the net of tax rate of interest across borders. From the perspective of a small open jurisdiction, a source tax on capital income increases the costs of capital in the jurisdiction and thus leads to capital outflows which again lower labor income (Wildasin and Wilson, 2004; Wildasin, 2003). In the words of Wildasin (2000), the immobile workers are left "holding the bag". The difficulty of carrying out redistributive taxation in the context of jurisdictional competition has been discussed mainly in static models emphasizing household mobility, migration externalities and problems of adverse selection. ${ }^{1}$

Recently Wildasin (2003) challenges the proposition that local capital taxes cannot be used to finance transfers to immobile households. He analyzes fiscal competition among jurisdictions in an explicitly dynamic framework, where it is costly and timeconsuming to adjust factor stocks, so the degree of capital mobility between jurisdictions is imperfect. ${ }^{2}$ This limited mobility makes it possible to tax private capital and redistribute income in the short run. Nevertheless in the long run taxation of mobile factors to 
redistribute income in favor of the owners of immobile resources becomes harmful. A similar message emerges from a dynamic model of imperfectly mobile capital developed by Wilson (1996).

The goal of the analysis presented here is to show a case where in a setting of perfect capital mobility fiscal policy allows for redistribution between perfectly mobile capital and immobile households in the long run. The theoretical framework presented in this paper differs in some respect from that used by Wildasin (2003). First, as mentioned, we assume private capital to be perfectly mobile across jurisdictional boundaries. Second, we assume that the government provides productive public inputs ${ }^{3}$ that can be considered as marginal product complements to private production factors and generate factor rents only to mobile capital. ${ }^{4}$ Third, we consider a small open and growing economy in which the owner of the immobile resource is treated as a representative single agent, who lives for two periods and in private decisions only cares about himself or herself and not about future generations, whereas Wildasin (2003) assumes an infinitely-lived private household. In addition, the government seeks to promote social welfare that is defined as the discounted utility functions of present and future generations. However, this distinguishing feature is not that important for the outcome of our model.

The paper is organized as follows. The model is described in Section 2. In Section 3 we deduce the welfare optimizing tax and investment strategy of a single small, open jurisdiction, where public decision-makers cannot directly control private investment or consumption but influence it through their tax instruments and the supply of productive infrastructure. Since taxation and infrastructure are factors in location decisions of mobile capital, jurisdictions simultaneously compete by means of tax and expenditure policies. To finance productive public infrastructure the government can choose between a source-based tax on capital revenue and a flat rate tax on wages. Section 4 concludes briefly.

\section{Dynamic Fiscal Competition with a Public Input}

\subsection{Production Technology}

Our first focus is the time-invariant production technology used in the jurisdiction. There are three factors of production: labor $L_{t}$, private capital $K_{t}$, and publicly provided capital $G_{t}$ which are used by private firms to produce one homogeneous good $Y_{t}$ at time $t$. The price of $Y_{t}$ is normalized to unity. Capital is simply non-consumed output. The production function $F\left(L_{t}, K_{t}, G_{t}\right)=Y_{t}$ exhibits positive diminishing marginal products with respect to each input, the Inada conditions hold, and technical progress is neglected. All factors are complements in the sense that the second-order cross derivations of $F\left(L_{t}, K_{t}, G_{t}\right)$ are positive. The public capital stock $G_{t}$ yields only production benefits, so that households are not immediate beneficiaries of public capital. The production function exhibits constant returns in $L_{t}, K_{t}$, and $G_{t}$. It is therefore concave and homogeneous to the degree of 1 and the public input can be interpreted as a publicly provided private good of "unpaid factor type". This assumption is crucial for our result and is still supported with some empirical evidence (Gramlich, 1994; Reiter and 
Weichenrieder, 1997). We assume that the government provides such public investment because exclusion is not possible and a market solution is thus unsatisfactory.

If the production function exhibits constant returns in $L_{t}, K_{t}$, and $G_{t}$, the output $Y_{t}$ can be decomposed into the imputed shares of labor, private capital and government capital according to Euler's theorem. Yet because the government supplies its services free of charge, entire output is not exhausted if all private inputs were paid their partial marginal product represented by the first partial derivative of $F\left(L_{t}, K_{t}, G_{t}\right)$ with respect to $K_{t}{ }^{5}$ In the following, we focus on a specific kind of public capital that is bound on private capital, so that private capital has some way to appropriate the public inputs' benefits and convert them into private capital income (Gramlich, 1994). Thus the government effectively provides a firm with $G_{t} / K_{t}$ units of public capital for each unit of private capital that it employs, where this ratio is fixed at its socially optimal level. It follows that the marginal revenue of private capital is $\partial F\left(L_{t}, K_{t}, G_{t}\right) / \partial K_{t}+\left[\partial F\left(L_{t}, K_{t}, G_{t}\right) / \partial G_{t}\right]\left(G_{t} / K_{t}\right)$. Note that public ownership of $G_{t}$ does not generate rents that directly enter the public budget.

$G_{t}$ is provided by the jurisdictional government in order to accommodate mobile capital $^{6}$ and can thus be considered as an instrument in jurisdictional competition. However, public infrastructure that generates a rent to mobile capital is not the only possible public input. More generally, we could assume that the government effectively provides a firm with $\omega G_{t} / K_{t}$ units of public capital for each unit of private capital it employs, and $(1-\omega) G_{t} / L_{t}$ units of public capital for each unit of labor. ${ }^{7}$ We discuss the general case, where private capital appropriates only a fraction $\omega<1$ of the public capital income, only briefly in note 10 and 11 .

\subsection{The Public and Private Sector}

2.2.1. Firms In the private sector, investment decisions are made by profit-maximizing firms. Capital has two costs to the firm, the rental price $r_{t}$ and a source-based tax on capital revenue, where $\theta_{K, t}$ denotes the capital tax rate. The RHS of (1) represent the user costs of private capital and the LHS of (1) can be considered as the marginal productivity of capital that exceeds the first partial derivative of $F\left(L_{t}, K_{t}, G_{t}\right)$ with respect to $K_{t}$ in this model. The firms invest capital up to the point where the marginal revenue of private investment equals the costs ${ }^{8}$ :

$$
\frac{\partial F\left(L_{t}, K_{t}, G_{t}\right)}{\partial K_{t}}+\frac{\partial F\left(L_{t}, K_{t}, G_{t}\right)}{\partial G_{t}} \frac{G_{t}}{K_{t}}=\frac{r_{t}}{1-\theta_{K, t}} .
$$

Since firms are free to invest and produce domestically or abroad, net of tax return of capital is the same everywhere $r_{t}=r^{*}$ and the supply of capital is completely price elastic. ${ }^{9}$ The marginal productivity of capital equals $r^{*} /\left(1-\theta_{K, t}\right)$, so the share of domestic income received by private capital is $K_{t} r^{*} /\left(1-\theta_{K, t}\right)$. The aggregate domestic wage income $W_{t}$ is a residual given by:

$$
Y_{t}-K_{t} \frac{r^{*}}{\left(1-\theta_{K, t}\right)}=W_{t}
$$

2.2.2. Households The household sector is designed according to the overlapping -generations model (Wildasin and Wilson, 1996). All people live for two periods, so 
at each point in time there are an old and a young generation living side by side. An individual born at time $t$ supplies a fixed amount of labor and pays a proportional tax rate $\theta_{L, t}$ on per capita wage income $w_{t}=W_{t} / L_{t}$. The economy's population grows at an exogenous rate $n$, thus $L_{t+1}=(1+n) L_{t}$. Since labor is supplied inelastically, the wage tax can be considered as equivalent to a lump sum tax. Note that the wage tax can be negative and thus be interpreted as a subsidy or a transfer to the households. From the perspective of the private agents, the fiscal parameters $G_{t}, \theta_{K, t}$, and $\theta_{L, t}$ are exogenous. Each young person consumes $c_{t}$ of the net income and saves the remainder $s_{t}=\left(1-\theta_{L, t}\right) w_{t}-c_{t}^{y}$. In the second period of his life the individual consumes all his wealth, both interest and principal $s_{t}\left(1+r^{*}\right)=c_{t+1}^{o}$. Like firms, private households have access to the world capital market so $r^{*}$ is the time-invariant return on private saving. Domestic and foreign claims on capital are assumed to be perfect substitutes as stores of value and no residence based tax on capital income is levied. The decision problem for young people is to maximize the lifetime $\log$ utility function $u\left(c_{t}^{y}, c_{t+1}^{o}\right)=\ln c_{t}^{y}+\vartheta \ln c_{t+1}^{o}$, with $0<\vartheta<1$, subject to the budget constraint

$$
c_{t}^{y}=\left(1-\theta_{L, t}\right) w_{t}-\frac{c_{t+1}^{o}}{\left(1+r^{*}\right)}
$$

so that the optimal consumption of somebody born in $t$ while old is $c_{t+1}^{o}=\vartheta\left(1+r^{*}\right) c_{t}^{y}$. The parameter $\vartheta$ denotes the subjective discount factor.

\subsubsection{Government The budget constraint of the public sector is given by}

$$
G_{t+1}-(1-\chi) G_{t}-\theta_{L, t} W_{t}-\theta_{K, t}\left(Y_{t}-W_{t}\right)=0 .
$$

The government's total tax revenue is the sum of the capital tax revenue $\left(Y_{t}-W_{t}\right) \theta_{K, t}$ and the wage tax revenue $W_{t} \theta_{L, t}$. Both tax rates are allowed to be time-variant. Public investment is $G_{t+1}-(1-\chi) G_{t}$, where $\chi$ denotes the depreciation rate. We leave open the possibility that the jurisdiction will choose negative tax rates and thus subsidize capital or labor. The residuum of the capital tax revenue minus the investment expenditures is the amount of wage tax borne by the workers or the transfer paid to them, if positive. Public consumption is neglected in the model.

\section{The Welfare Maximizing Tax and Investment Strategy of an Autonomous Jurisdiction}

Since we seek the optimal tax and investment strategy of an autonomous jurisdiction it is necessary to specify a criterion function by which optimality can be judged. Therefore we assume that the government has the objective to maximize the utility of its residents and discounts the utility of future generations at rate $\lambda$. This implies an infinite-horizon social welfare function of the form $\Psi=u\left(c_{t}^{o}\right)+\sum_{t=1}^{\infty}(1+\lambda)^{1-t} u\left(c_{t}^{y}, c_{t+1}^{o}\right)$. If the government cares less about future generations, $\lambda$ is positive. $\Psi$ converges under the condition of a positive social discount rate $\lambda$ and the stationarity assumption of $u\left(c_{t}^{y}, c_{t+1}^{o}\right)$. The government maximizes the welfare function subject to the two private constraints (1) and (3), the optimality condition of the private household $c_{t+1}^{o}=\vartheta\left(1+r^{*}\right) c_{t}^{y}$, and the public budget constraint (4). Further, an additional constraint holds that $G_{1}$ is given. 
Accordingly, the Lagrangian expression is

$$
\begin{aligned}
Z & \left(\theta_{K, t}, \theta_{L, t}, G_{t+1}, c_{t}^{y}, K_{t}\right) \\
= & \Psi+\sum_{t=1}^{\infty} \mu_{t}\left[\theta_{L, t} W_{t}+\theta_{K, t}\left(Y_{t}-W_{t}\right)-G_{t+1}+(1-\chi) G_{t}\right] \\
& +\sum_{t=1}^{\infty} \rho_{t}\left[\left(Y_{t}-W_{t}\right)-\left(Y_{t}-W_{t}\right) \theta_{K, t}-r^{*} K_{t}\right] \\
& +\sum_{t=1}^{\infty} \delta_{t}\left[\frac{W_{t}}{L_{t}}-\frac{W_{t}}{L_{t}} \theta_{L, t}-(1+\vartheta) c_{t}^{y}\right]
\end{aligned}
$$

where the Lagrange multipliers $\mu_{t}, \rho_{t}$, and $\delta_{t}$ are functions of the time $t$.

\subsection{Optimal Source Tax}

From the first-order conditions of the optimization problem-presented in the Appendix — we first deduce the optimal source tax rate

$$
\theta_{K, t}^{*}=\frac{\left(Y_{t}-W_{t}\right)-\frac{\partial Y_{t}}{\partial K_{t}} K_{t}}{\left(Y_{t}-W_{t}\right)}
$$

From equations (1) and (6) it can be seen that the optimal local public policy taxes away the rents appropriated by the private capital so that the corresponding tax revenue

$$
\theta_{K, t}^{*}\left[K_{t} \frac{\partial Y_{t}}{\partial K_{t}}+\frac{\partial Y_{t}}{\partial G_{t}} G_{t}\right]=\frac{\partial Y_{t}}{\partial G_{t}} G_{t}
$$

equals exactly the share of public capital income $\left(\partial Y_{t} / \partial G_{t}\right) G_{t}$. Further, it becomes clear that only public capital that generates a capital rent justifies the taxation of mobile capital. $^{10}$

Note that in period $t$ the optimal capital tax revenue is not directly dependent on the level of public expenditure and that if $\theta_{K, t}=\theta_{K, t}^{*}$, the partial productivity of private capital $\partial Y_{t} / \partial K_{t}$ equals exactly $r^{*}$. From (3) we know that $r^{*}$ is the return on private savings no matter whether these savings are invested in the jurisdiction or somewhere else. Thus the private capital will now be exactly as productive within the jurisdiction as its opportunity costs to the residence. Lowering taxation of the mobile capital would lower the productivity of private capital in the jurisdiction beyond its opportunity costs and the gain of wage income induced by the capital inflow would not be compensated by the loss of tax revenue. Since the public budget must be balanced in each period, this loss of tax revenue either lowers the subsidies paid to the private household or raises wage taxes. On the other hand a tax rate above $\theta_{K, t}^{*}$ would raise the marginal productivity of private capital above the opportunity costs of private capital. 
3.1.1. Benefit Tax This result of an optimal source tax on capital rents points to a view on fiscal competition held by Oates and Schwab (1991) and Oates (1999) and discussed by Gerber and Hewitt (1987), Richter (1994) and Zodrow (2001). According to them, the incidence of a source tax is quite different from the classical view (Wellisch, 2000; Wildasin, 2003; Wildasin and Wilson, 2004). The intuition is that if the capital tax revenue is used by the government to supply public infrastructure that improves the productivity of private capital, the tax-induced increase of the costs of capital in the jurisdiction will be compensated by an increase in the return of capital and thus counteract the capital outflow. Arguing in the Tiebout tradition, Oates (1999) takes the view that if many jurisdictions compete against one another, all taxes levied by the jurisdiction will become user charges for local public goods. In this context a source-based capital tax should be interpreted as a price for public services. Nevertheless, as shown by equation (6) a benefit tax on private capital is only justified if public infrastructure generates a factor rent on private capital.

\subsection{A Modified Golden Rule of Government Investment}

This section investigates how much of the optimal source tax revenue-equivalent to the output share of the public capital-must be used to finance public inputs and whether some revenue of a source-based capital tax can be used to finance transfers or a negative wage tax to private households. As is well known, taxes are not earmarked so the source tax revenue need not compellingly be pumped into public investment expenditure. Whether the wage tax is positive or negative depends on the relation of the public investment level and the appropriated income share of public capital. If the tax revenue exceeds public investment, the wage tax rate becomes negative which means that workers receive income transfer from the government. Thus the question that suggests itself is what level of investment a benevolent government will choose.

From the optimization problem (5) we receive the optimal investment path of the jurisdictional government as

$$
\frac{\partial Y_{t+1}}{\partial G_{t+1}}=(1+\lambda)(1+n) \frac{\frac{\partial u\left(c_{t}^{y}, c_{t+1}^{o}\left(c_{t}^{y}\right)\right)}{\partial c_{t}^{y}}}{\frac{\partial u\left(c_{t+1}^{y}, c_{t+2}^{o}\left(c_{t+1}^{y}\right)\right)}{\partial c_{t+1}^{y}}}-(1-\chi)
$$

(see Appendix for details). Equation (7) is a condition for optimal intertemporal allocation. It can be interpreted as a modified golden rule of government investment (Barro and Sala-i-Martin (1995), p. 74). Condition (7) states that decreasing lifetime consumption for the individuals working in period $(t)$ leads to a decrease of their utility $L_{t} \frac{\partial u\left(c_{t}^{y}\right)}{\partial c_{t}^{y}}$ but makes an increase in utility of the individuals working in period $(t+1)$ possible through public capital accumulation. According to the optimality condition, this utility increase discounted to $t$ using the social discount rate $\lambda$ has to equal the initial utility decrease. 


\subsection{Redistribution in the Steady State}

According to the public budget constraint (4), condition (2) and (6), the wage tax revenue is the residual

$$
G_{t+1}-(1-\chi) G_{t}-G_{t} \frac{\partial Y_{t}}{\partial G_{t}}=\theta_{L, t} W_{t} .
$$

It is negative if the aggregate investment level of the government is lower than the optimal capital tax revenue. In the steady state the per capita amounts of the public capital stock $g_{t}=G_{t} / L_{t}$ is constant over time, so $g_{t}=g_{t+1}$ holds. Thus the aggregate steady state investment level of the government is $(n+\chi) G_{t}$. In the long run, the wage tax revenue is negative and thus a transfer to workers if $(n+\chi)$ is less than the marginal productivity of public capital. From (7) we know that this condition always holds, if the social discount rate $\lambda$ is positive, so that the government does not invest according to Ramsey's golden rule of investment, but according to the modified golden rule. ${ }^{11}$ To illustrate our results, we make the assumption that the production function shows constant output elasticity with respect to labor $\alpha$, private capital $\beta$ and public capital $\varepsilon$, with $\alpha+\beta+\varepsilon=1$. Using (1) and (5), we receive the optimal capital tax rate $\theta_{K}^{*}=\varepsilon /(\beta+\varepsilon)$ and the capital tax revenue $\varepsilon Y_{t}$. Under the assumptions made, in the long run the marginal productivity of public capital is time-invariant and equals $\varepsilon Y_{t} / G_{t}=(1+\lambda)(1+n)-(1-\chi)$. Thus the tax burden borne by the immobile factor labor is given by $\theta_{L} W_{t}=-\lambda(1+n) G_{t}$.

Let us briefly compare this result with that derived by Oates and Schwab (1991), Wellisch (1995, p. 83) and Gerber and Hewitt (1987, p. 456) who make assumptions about technology that are very similar to our model. These authors suggest that decentralized levels of government should avoid non-benefit taxes on highly mobile capital (Oates, 1999, p. 1125). According to Oates and Schwab (1991, p. 127) one “...can not expect to find that revenue from local taxes levied on business would be used to fund social programs, parks, education and the like." They conclude that the source tax revenue has to be entirely used to finance public inputs. Since the authors argue in a one-period model, they cover the case where a benevolent government does not care about intertemporal social welfare but just maximizes steady state welfare. Applied to our model, the authors argue under the condition that $\lambda=0$, under which even in a growing economy all source tax revenue must be used to finance public investments and no tax revenue is left over for redistribution. Comparing the discussed static models with our model, their different assumption about the social discount rate causes different results.

\section{Conclusion}

This paper presents an explicitly dynamic analysis of fiscal competition under the assumption of perfect capital mobility. Additionally, we assume that the government of a small and autonomous jurisdiction provides productive public inputs of the so-called "unpaid factor type" that create rents which can be appropriated by the private capital. Thus private capital is paid more than its partial marginal product, i.e. the first partial derivative of $F\left(L_{t}, K_{t}, G_{t}\right)$ with respect to $K_{t}$. Our analysis shows that a benevolent public decision-maker within a decentralized, autonomous jurisdiction prefers a source 
tax on mobile capital that taxes away factor rents to a wage tax on immobile labor. We further demonstrate that portions of the source tax revenue can be used for redistributive programs, as income transfers to immobile private households. Nevertheless, our results are based on the conditions that (i) private capital can appropriate public inputs' benefits and that (ii) the benevolent government maximizes an intertemporal welfare by discounting the utility of future generations at a positive factor. Under this condition, the modified golden rule of public investment deduced in the model states that the factor rents generated by public inputs exceed the optimal steady state level of public investment.

\section{Appendix}

This Appendix presents some results derived in the text.

\section{A. Derivation of (6)}

$$
\begin{aligned}
& \frac{\partial \mathrm{Z}}{\partial \theta_{L, t} W_{t}}=\mu_{t}-\delta_{t} \frac{1}{L_{t}}=0 \\
& \frac{\partial \mathrm{Z}}{\partial \theta_{K, t}\left(Y_{t}-W_{t}\right)}=\mu_{t}-\rho_{t}=0 \\
& \frac{\partial \mathrm{Z}}{\partial K_{t+1}}=\rho_{t+1}\left[\frac{\partial\left(Y_{t+1}-W_{t+1}\right)}{\partial K_{t+1}}-r^{*}\right]+\delta_{t+1}\left[\frac{\partial W_{t+1}}{L_{t+1} \partial K_{t+1}}\right]=0 \\
& \left.\rho_{t+1}=-\frac{\delta_{t+1}\left[\frac{\partial W_{t+1}}{L_{t+1} \partial K_{t+1}}\right]}{\left.\partial Y_{t+1}-W_{t+1}\right)}-r^{*}\right] \\
& \frac{\partial \mathrm{Z}}{\partial c_{t}^{y}}=(1+\lambda)^{-t} \frac{\partial u\left(c_{t}^{y}\right)}{\partial c_{t}^{y}}-\delta_{t}(1+\vartheta)=0 \quad \delta_{t}=\frac{(1+\lambda)^{-t}}{1+\vartheta} \frac{\partial u}{\partial c_{t}^{y}}
\end{aligned}
$$

Substituting (12) into (9)

$$
\mu_{t}=\frac{(1+\lambda)^{-t}}{1+\vartheta} \frac{\partial u\left(c_{t}^{y}\right)}{\partial c_{t}^{y}} \frac{1}{L_{t}}
$$

Substituting (12) into (10)

$$
\mu_{t}=-\frac{\frac{(1+\lambda)^{-t}}{1+\vartheta} \frac{\partial u\left(c_{t}^{y}\right)}{\partial c_{t}^{y}}\left[\frac{\partial W_{t}}{L_{t} \partial K_{t}}\right]}{\left[\frac{\partial\left(Y_{t}-W_{t}\right)}{\partial K_{t}}-r^{*}\right]}
$$

From (2) we know $r_{t}^{*}=\frac{\left(Y_{t}-W_{t}\right)-\theta_{K, t}\left(Y_{t}-W_{t}\right)}{K_{t}}$ which leads to the optimal tax rate presented in equation (6). 


\section{B. Derivation of (7)}

$$
\begin{aligned}
\frac{\partial \mathrm{Z}}{\partial G_{t+1}}= & -\mu_{t}+\mu_{t+1}(1-\chi)+\rho_{t+1}\left[\frac{\partial\left(Y_{t+1}-W_{t+1}\right)}{\partial G_{t+1}}\right] \\
& +\delta_{t+1}\left[\frac{\partial W_{t+1}}{L_{t+1} \partial G_{t+1}}\right]=0
\end{aligned}
$$

Eliminating the Lagrange parameters $\mu_{t}, \mu_{t+1}, \rho_{t+1}$, and $\delta_{t+1}$ and replacing $\theta_{K, t}^{*}$ according to (5) we receive the modified golden rule of public investment presented in (7).

\section{Acknowledgment}

I thank John D. Wilson and two anonymous referees for helpful comments.

\section{Notes}

1. For a survey of the literature see Wellisch (2000).

2. Wildasin (2003) provides a brief survey of previous studies in the field of intertemporal fiscal competition.

3. Public input within a fiscal competition framework has been discussed by Zodrow and Mieszkowski (1986), Gerber and Hewitt (1987), Oates and Schwab (1991), Taylor (1992), Richter (1994), Richter and Wellisch (1996), Keen and Marchand (1997), and others (see Matsumoto (2000) and references therein). Most of these authors focus on the question whether tax competition leads to a sub-optimal provision of public inputs by employing different tax instruments, different assumptions about the number of competing jurisdictions and their strategic interaction. In principle they confirm the well-known underprovision result of public inputs in tax competition. The possibility of overprovision is discussed by Bayindir-Upmann (1998), Noiset (1995) and Noiset and Oakland (1995). In none of the models would it be efficient to impose a source tax on a mobile tax base that exceeds the costs of providing public inputs.

4. Most tax competition studies of local public inputs presented in the literature focus either on the factoraugmenting type of public input that generate no rents, or on public inputs of the unpaid factor type that only generate rents to the immobile factor. Richter (1994) and Matsumoto $(1998,2000)$ allow for firm-augmenting public inputs that benefit mobile firms. Gerber and Hewitt (1987) and Oates and Schwab (1991) consider public inputs that generate rents to mobile capital. Feehan (1989) reviews alternative specifications of public input. Sinn (1997) does not focus on the role of public goods in the production function, but on the costs of using public infrastructure and according congestion externality.

5. Euler's Theorem states that under homogeneity of degree 1, a function can be reduced to the sum of its arguments multiplied by its first partial derivatives.

6. Because all production factors are complements in the sense that the second-order cross derivations of $F\left(L_{t}, K_{t}, G_{t}\right)$ are positive, there are additionally so called indirect productivity effects on private labor and private capital. Nevertheless, we will show that this indirect productivity effect does not justify to tax mobile capital.

7. In addition we could assume that the public inputs is of the so-called "creation of atmosphere type" and thus generate no factor rents. In this case, the production function exhibits increasing returns to scale in all three inputs, but constant returns to scale in the private inputs alone. The "factor-augmenting type" of public input discussed by Matsumoto (1998) is similar to the "creation of atmosphere type" described by Meade (1952).

8. Kim und Wilson (1997) present a model where pollution emissions replace the public input $G_{t}$ and the production function exhibits constant returns to scale in capital, labor and pollution emission. In the model, labor appropriates the factor rent generated by pollution. 
9. In the standard model of a small open economy private and public decision makers face an exogenous world interest rate, whereas the tax and investment policy of a more centralized government may affect the world interest rate.

10. If the publicly supplied capital is entirely bound by an immobile factor or if it is from the creation of atmosphere type, private capital cannot appropriate any rents. Equation (2) shows that in this case $\left(Y_{t}-W_{t}\right)=\frac{\partial Y_{t}}{\partial K_{t}} K_{t}$ holds and $\theta_{K, t}^{*}=0$. This is the well known result of Zodrow and Mieszkowski (1986), according to which the government does not tax mobile capital to finance any kind of public expenditure. If only a part $0<\omega<1$ of the public infrastructure supply accrues to private capital the optimal source tax revenue is $\omega \frac{\partial Y_{t}}{\partial G_{t}} G_{t}$. In an environment of tax competition and perfect capital mobility the assumption $\omega>0$ is necessary to make a source tax an efficient tax instrument at all (Oates and Schwab, 1991; Gerber and Hewitt, 1987).

11. If we again make the assumption that private capital appropriates only a fraction $\omega<1$ of the public capital income, the wage tax becomes negative if $\lambda>\frac{(1-\omega)}{\omega} \frac{(\chi+n)}{(1+n)}$ holds. If the population growth and the depreciation rate are assumed to be very small, public investment that is needed to maintain the public capital stock $(n+\chi) G_{t}$ is also very small. For a positive social discount rate $\lambda$ the optimal source tax revenue $\omega \frac{\partial Y_{t}}{\partial G_{t}} G_{t}$ may exceed this investment expenditure even if $\omega$ is considerable less than one.

\section{References}

Barro, R. J. and X. Sala-i-Martin. (1995). Economic Growth. McGraw-Hill.

Bayindir-Upmann, T. (1998). "Two Games of Interjurisdictional Competition when Local Governments Provide Industrial Public Goods," International Tax and Public Finance 5, 471-487.

Feehan, P. (1989). "Pareto-Efficiency with Three Varieties of Public Input," Public Finance 44, 237-248.

Gerber, R. I. and D. P. Hewitt. (1987). "Decentralized Tax Competition for Business Capital and National Economic Efficiency," Journal of Regional Science 27, 451-460.

Gramlich, E. M. (1994). "Infrastructure Investment: A Review Essay," Journal of Economic Literature 32, 1176-1196.

Keen, M. J. and M. Marchand. (1997). "Fiscal Competition and the Pattern of Public Spending," Journal of Public Economics 66, 33-53.

Kim, J. and J. D. Wilson. (1997). "Capital Mobility and Environmental Standards: Racing to the Bottom with Multiple Tax Instruments,” Japan and the World Economy 9, 537-551.

Matsumoto, M. (1998). “A Note on Tax Competition and Public Input Provision,” Regional Science and Urban Economics 28, 465-473.

Matsumoto, M. (2000). "A Tax Competition Analysis of Congestible Public Inputs," Journal of Urban Economics 48, 242-259.

Meade, J. E. (1952). "External Economies and Diseconomies in a Competitive Situation,” Economic Journal 62, 54-67.

Noiset, L. (1995). "Pigou, Tiebout, Property Taxation, and the Underprovision of Local Public Goods: Comment," Journal of Urban Economics 38, 312-316.

Noiset, L. and W. H. Oakland. (1995). "The Taxation of Mobile Capital by Central Cities," Journal of Public Economics 57, 297-316.

Oates, W. E. (1999). “An Essay on Fiscal Federalism,” Journal of Economic Literature 37, 1120-1149.

Oates, W. E. and R. M. Schwab. (1991). "The Allocative and Distributive Implications of Local Fiscal Competition.” In Kenyon, Daphne A. and Albert Breton (eds.), Competition Among State and Local Governments. Washington D.C., 127-145.

Reiter, M. and A. J. Weichenrieder. (1997). "Are Public Goods Public? A Critical Survey of the Demand Estimates for Local Public Services," Finanzarchiv 54, 374-408.

Richter, W. F. (1994). "The Efficient Allocation of Local Public Factors in Tiebout's Tradition," Regional Science and Urban Economics 24, 323-340.

Richter, W. F. and D. Wellisch. (1996). "The Provision of Local Public Goods and Factors in the Presence of Firm and Household Mobility," Journal of Public Economics 60, 73-93.

Sinn, H.-W. (1997). "The Selection Principle and Market Failure in Systems Competition," Journal of Public Economics 66, 247-274. 
Taylor, L. (1992). "Infrastructural Competition Among Jurisdictions,” Journal of Public Economics 49, 241259.

Wellisch, D. (1995). Dezentrale Finanzpolitik bei hoher Mobilität. Tübingen: Mohr.

Wellisch, D. (2000). Theory of Public Finance in a Federal State. Cambridge University Press.

Wildasin, D. E. (2000). "Factor Mobility and Fiscal Policy in the EU: Policy Issues and Analytical Approaches," Economic policy: A European Forum October, 337-368.

Wildasin, D. E. (2003). "Fiscal Competition in Space and Time," Journal of Public Economics 87, 2571-2588.

Wildasin, D. E. and J. D. Wilson. (1996). "Imperfect Mobility of Local Government Behavior in an Overlapping-Generations Model," Journal of Public Economics 60, 177-198.

Wildasin, D. E. and J. D. Wilson. (2004). “Capital Tax Competition: Bane or Boon?” Journal of Public Economics 88, 1065-1091.

Wilson, J. D. (1996). "The Tax Treatment of Imperfectly Mobile Firms: Rent Seeking, Rent Protection, and Rent Destruction," In R. C. Feenstra, Gene M. Grossman, and Douglas A. Irvin (eds.), The Political Economy of Trade: Essays in Honor of Jagdish Bhagwati. Cambridge, MA: M.I.T. Press.

Zodrow, G. R. (2001). “The Property Tax as a Capital Tax: A Room with Three Views," National Tax Journal $54,139-156$.

Zodrow, G. R. and P. M. Mieszkowski. (1986). "Pigou, Tiebout, Property Taxation, and the Under-Provision of Local Public Goods," Journal of Urban Economics 19, 356-370. 
